\title{
Production and Foreign Trade of Mineral Products in Latvia and Belarus
}

\author{
Ilze Sproge ${ }^{1}$, Irina Curkina ${ }^{1}$, Sandra Jekabsone ${ }^{2}$, \\ Valentina Tsilibina ${ }^{3}$, Julia Rumyantseva ${ }^{3}$, Kirill Piletsky ${ }^{3}$ \\ 1 - Institute for National Economy Research, Sandra Jekabsone, 2 - University of Latvia, \\ 3 - The Institute of Economics of the NAS of Belarus
}

\begin{abstract}
Latvia and Belarus are small countries with limited scope of natural resources. However, the available mineral resources play important role in production of mineral products for domestic and foreign consumption. Main goal of the paper is to characterize the role of extraction industry in national economy and mineral products trade in two neighboring countries - Latvia and Belarus. To achieve the goal, the role of mining and quarrying industry in Latvia and Belarus was identified; trade of mineral resources in Latvia was analyzed. The main trends in the development of its own mineral resources of the Republic of Belarus were identified, the role of mineral resources in the commodity structure of foreign trade of the Republic of Belarus was shown, ways to increase the level of security of the country's own organic and mineral resources were determined, including the improvement of the legal framework. The research was performed in 2012; the following methods were used in the paper: comparative analysis and synthesis, statistical analysis and monographic methods.
\end{abstract}

Keywords - mineral resources, subsoil use, mineral products, economic development, foreign trade.

\section{INTRODUCTION}

The global economy of mineral resources and mineral commodities is being characterized by the presence of such processes as the emergence and development of the market of mineral bases and intensification of the processes of globalization of markets of mineral mineral products.

The development of national economies and the world economy as a whole depends on how fully meet their needs in mineral commodities.

\section{THE PLACE OF MINING INDUSTRY IN NATIONAL ECONOMY AND MINERAL'S FOREIGN TRADE IN LATVIA 2005-2011}

An insight into the mining industry's role in the economy can be obtained by analysis of value added, as well as foreign trade data, which describes dynamics of foreign and domestic consumption of mineral products.

The value added of mining and quarrying in Latvia is almost $10 \%$ of the EU-27 average, there are about 200 companies operating in the industry. Compared with its Baltic neighbours, the value added in mining industry in Latvia is lower: value added in Estonia in 2010 was 140 million EUR, in Lithuania 71 million EUR, but in Latvia only 59 million EUR. The share of value added, created in mining and quarrying industry in Latvia in 2011 was $0.5 \%$ of GDP [1]. In comparison, in Republic of Belarus the share was higher: $1.1 \%$ of GDP [11].

The mineral resource range of Latvia basically meets the needs of the construction sector as well as the foreign demand for non-metallic mineral products.

During the period from 2005 to 2011, the import of goods and services in Latvia exceeded the export value.

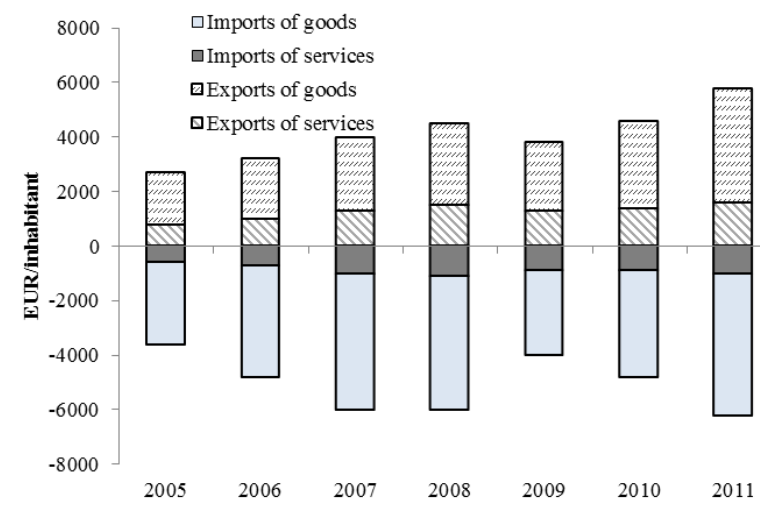

Fig.1. Foreign trade of goods and services in Latvia, 2005-2011

The foreign trade of mineral products has increased following the transition to the market economy (Table I).

TABLE I

SHARE OF MINERAL PRODUCT EXPORTS AND IMPORTS IN LATVIA, \% OF TOTAL TRADE VALUE [1]

\begin{tabular}{|c|c|c|c|c|}
\hline Indicator / year & 2005 & 2009 & 2010 & 2011 \\
\hline Total import value & $100.0 \%$ & $100.0 \%$ & $100.0 \%$ & $100.0 \%$ \\
\hline $\begin{array}{l}\text { Mineral products import } \\
\text { value } \% \text { of total, of which }\end{array}$ & $15.5 \%$ & $17.2 \%$ & $15.4 \%$ & $17.3 \%$ \\
\hline -diesel oil & $34.2 \%$ & $27.6 \%$ & $31.8 \%$ & $32.8 \%$ \\
\hline $\begin{array}{l}\text {-motor spirit (excl. } \\
\text { aviation spirit) }\end{array}$ & $16.8 \%$ & $13.8 \%$ & $10.8 \%$ & $9.7 \%$ \\
\hline $\begin{array}{l}\text {-coal; briquettes and } \\
\text { similar solid fuel }\end{array}$ & $0.6 \%$ & $0.6 \%$ & $0.9 \%$ & $0.9 \%$ \\
\hline Total export value & $100.0 \%$ & $100.0 \%$ & $100.0 \%$ & $100.0 \%$ \\
\hline $\begin{array}{l}\text { Mineral products export } \\
\text { value } \% \text { of total, of which }\end{array}$ & $9.2 \%$ & $5.5 \%$ & $6.0 \%$ & $9.1 \%$ \\
\hline -cement & $0.3 \%$ & $2.7 \%$ & $7.6 \%$ & $6.2 \%$ \\
\hline -peat & $11 \%$ & $27 \%$ & $23 \%$ & $13 \%$ \\
\hline
\end{tabular}


As shown in Table I, mineral product import in Latvia in year 2011 accounted for $17.3 \%$ (1 903 mln.EUR) from the value of all imported commodities. Machinery and mechanical appliances; electrical equipment accounted for a similar proportion $(17.3 \%)$ of total goods imports. The third largest group of imported goods is food and agricultural products ( $15.1 \%$ of total imports). These three commodity groups account for $50 \%$ of the total value of imported goods in 2011. Thus, compared with 2005 , the proportion of mineral products in the total value of imported goods has increased by nearly two percentage points.

When assessing the value dynamics of imported mineral products during the period from 2005 to 2011 , it can be concluded that the most rapid increase in import is attributable to solid fuel (coal, briquettes and similar solid fuel).

The export of cement and peat accounts for $20 \%$ of exported mineral product revenues, the income from cement exports is rising since 2005. In 2005 the exported cement value was 1022 thsd.EUR and in year 2011 - 48054 thsd.EUR.

According to the foreign trade data, the trade (both export and import value) with Belarus is growing over time. However, the Latvian foreign trade balance with Belarus since 2005 has worsened. In 2005, the difference between the export income from marketed products in Belarus and import expenditure was -94 million EUR, but in 2011 it was -305 million EUR. This can be explained by the fact that the value of imported goods from Belarus has historically been higher than the export earnings of the trade. The value of foreign trade in non-metallic mineral manufactures has increased significantly over the time: according to statistical data, the export income rose 8 times since year 2000, but import value - doubled in 2011/2000. Table II demonstrates Latvian foreign trade value of non-metallic mineral manufactures by region in year 2011.

TABLE II

MINERAL PRODUCT EXPORTS AND IMPORTS BY PARTNER IN LATVIA (2011), MLN.EUR [3]

\begin{tabular}{|l|l|l|l|}
\hline Product/partner & Belarus & $\begin{array}{l}\text { EU27-extra } \\
\text { (incl.Belarus) }\end{array}$ & $\begin{array}{l}\text { EU27- } \\
\text { intra }\end{array}$ \\
\hline Total imports & $\mathbf{4 8 3 . 5}$ & $\mathbf{2 6 2 0 . 5}$ & $\mathbf{9 0 8 2 . 0}$ \\
\hline $\begin{array}{l}\text { Non-metallic mineral } \\
\text { manufactures (SITC 66) }\end{array}$ & 3.9 & 24.3 & 138.8 \\
\hline $\begin{array}{l}\text { Lime, cement, } \\
\text { construction materials } \\
\text { (SITC 661) }\end{array}$ & 0.4 & 7.4 & 14.1 \\
\hline $\begin{array}{l}\text { Clay construction } \\
\text { materials, refractory } \\
\text { construction materials } \\
\text { (SITC 662) }\end{array}$ & 0.3 & 1.7 & 25.3 \\
\hline $\begin{array}{l}\text { Mineral manufactures, } \\
\text { n.e.s. (SITC 663) }\end{array}$ & 1.7 & 4.5 & 39.5 \\
\hline Glass (SITC 664) & 0.5 & 5.9 & 23.2 \\
\hline Total exports & 179.4 & 3208.2 & 6224.5 \\
\hline
\end{tabular}

\begin{tabular}{|l|l|l|l|}
\hline Product/partner & Belarus & $\begin{array}{l}\text { EU27-extra } \\
\text { (incl.Belarus) }\end{array}$ & $\begin{array}{l}\text { EU27- } \\
\text { intra }\end{array}$ \\
\hline $\begin{array}{l}\text { Non-metallic mineral } \\
\text { manufactures (SITC 66) }\end{array}$ & 6.0 & 59.2 & 92.0 \\
\hline $\begin{array}{l}\text { Lime, cement, } \\
\text { construction materials } \\
\text { (SITC 661) }\end{array}$ & 4.6 & 22.1 & 29.1 \\
\hline $\begin{array}{l}\text { Clay construction } \\
\text { materials, refractory } \\
\text { construction materials } \\
\text { (SITC 662) }\end{array}$ & 0.2 & 15.1 & 6.8 \\
\hline $\begin{array}{l}\text { Mineral manufactures, } \\
\text { n.e.s. (SITC 663) }\end{array}$ & 1.0 & 7.6 & 35.2 \\
\hline Glass (SITC 664) & 0.1 & 10.3 & 15.7 \\
\hline
\end{tabular}

When assessing the foreign trade value dynamics of mineral products between Latvia and Belarus, the following trends can be identified.

In the 3rd SITC group of mineral fuels, lubricants and related materials, Belarus is an important petroleum, petroleum product and related material import market. In 2000, the EU share was $27 \%$ of the import value of petroleum, Belarus $27 \%$ and other countries $-46 \%$. In year 2011 the role of the third countries in petroleum imports decreased, while the share of the EU increased. Thus, $69 \%$ of the petroleum import value is attributable to the EU-27, $24 \%$ to Belarus and $7 \%$ to other countries.

In the 66th SITC group of non-metallic mineral manufactures since 2005 the foreign trade balance has improved. In 2005 the value of non-metallic mineral manufactures, imported from Belarus was 4 million EUR; the export income was 0.5 million EUR. In 2011 the value of imported non-metallic mineral manufactures was 4 million EUR, but export income rose to 6 million EUR.

Mineral manufactures not specified (group 663) accounted for $44 \%$ of mineral product import from Belarus. Glassware (SITC 665) was next most significant import product from Belarus in 2011, following by glass (SITC 664) with share of $24 \%$ and $12 \%$ accordingly.

In non-metallic mineral manufactures trade, $77 \%$ Latvian income was guaranteed by the export of the sub-group 661 (lime, cement, and fabricated construction materials, except glass and clay materials). Trade in these construction materials provided a positive balance of foreign trade with Belarus in both the 2010 and 2011. In comparison, in year 2005 the import value of construction materials from Belarus was $1.5 \mathrm{mln} . E U R$, and export income 0.3 mln.EUR.

Summarizing, it can be concluded, that trade in mineral products between Latvia and Belarus is increasing in observed time period 2005-2011.

\section{MINERAL PRODUCT INDUSTRY AND TRADE CHARACTERISTICS IN BELARUS 2005- 2011}

The Republic of Belarus refers to a group of small countries that do not have sufficient own mineral resources, therefore forced to import them, so far as 
based on mineral commodities to end use or for produce a finished product the following industries have been functioning: fuel industry, chemical and petrochemical industry, electricity, ferrous metallurgy, building materials industry (Table III).

TABLE III

DYNAMICS OF PRODUCTION OF MAJOR PRODUCTS IN THE REPUBLIC OF BELARUS IN 2005-2011 YEARS BASED ON MINERAL COMMODITIES

\begin{tabular}{|c|c|c|c|c|c|c|c|c|}
\hline Product type & Unit & 2005 & 2006 & 2007 & 2008 & 2009 & 2010 & 2011 \\
\hline \multicolumn{9}{|l|}{ Fuel industry } \\
\hline Oil (including gas condensate) & thous. tonnes & 1785 & 1780 & 1760 & 1740 & 1720 & 1700 & 1681 \\
\hline Natural gas & $\mathrm{mln} \mathrm{m}^{3}$ & 228 & 219 & 201 & 203 & 205 & 213 & 222 \\
\hline $\begin{array}{l}\text { Peat fuel (of conventional moisture } \\
\text { content) }\end{array}$ & thous. tonnes & 2307 & 2125 & 2502 & 2361 & 2216 & 2352 & 2823 \\
\hline \multicolumn{9}{|l|}{ Chemical and petrochemical industry } \\
\hline $\begin{array}{l}\text { Total mineral fertilizers, } \\
\text { of which: }\end{array}$ & thous. tonnes & 5669 & 5469 & 5880 & 5870 & 3390 & 6176 & 6288 \\
\hline nitrogenous & -“- & 684 & 711 & 751 & 728 & 728 & 761 & 798 \\
\hline potassium & -“- & 4844 & 4605 & 4972 & 4976 & 2485 & 5223 & 5306 \\
\hline phosphate & $-“-$ & 141 & 153 & 157 & 175 & 177 & 192 & 185 \\
\hline $\begin{array}{l}\text { Fodder yeast (based substrates oil } \\
\text { fractions) }\end{array}$ & -“- & 24,3 & 31,8 & 32,9 & 32,5 & 33,6 & 20,3 & 7,6 \\
\hline \multicolumn{9}{|c|}{ Production of major products of refining industry } \\
\hline Primary crude oil processing & thous. tonnes & 19802 & 21253 & 21349 & 21304 & 21634 & 16455 & 20474 \\
\hline Petrol & -“- & 3763 & 3931 & 3702 & 3709 & 3671 & 3477 & 3693 \\
\hline of which motor petrol & $\begin{array}{ll}-“- \\
-\end{array}$ & 3330 & 3498 & 3181 & 3330 & 3372 & 3158 & 3135 \\
\hline Diesel fuel & -“- & 6426 & 6616 & 6679 & 661 & 6588 & 5331 & 6709 \\
\hline Fuel oil (gross output) & $-“-$ & 6313 & 6329 & 6195 & 5913 & 6202 & 4421 & 5589 \\
\hline \multicolumn{9}{|c|}{ Production of thermal and electrical energy } \\
\hline Electrical energy & billion $\mathrm{kWh}$ & 30,961 & 31,811 & 31,829 & 35,054 & 30,405 & 34,890 & 32,192 \\
\hline The thermal energy & mln Gcal & 73,496 & 74,383 & 69,733 & 67,454 & 67,769 & 72,475 & 68,960 \\
\hline \multicolumn{9}{|l|}{ Building materials industry } \\
\hline Cement & thous. tonnes & 3131 & 3495 & 3821 & 4219 & 4350 & 4531 & 4604 \\
\hline $\begin{array}{l}\text { Wall materials, all } \\
\text { of them: }\end{array}$ & $\begin{array}{l}\text { mln standard } \\
\text { bricks }\end{array}$ & 2960,4 & 3640,6 & 4193,9 & 4389,2 & 3729,3 & 4087,3 & 4249,0 \\
\hline building bricks & -“- & 838,1 & 934,9 & 1084,4 & 1102,8 & 960,4 & 1002,3 & 955,9 \\
\hline wall blocks of cellular concrete & -“- & 1964,3 & 2477,6 & 2829,8 & 2982,0 & 2456,2 & 2772,4 & 2971,5 \\
\hline Lime & thous. tonnes & 785 & 853 & 925 & 900 & 788 & 804 & 793 \\
\hline Limestone and dolomite flour & mln tonnes & 2,506 & 2,273 & 2,092 & 1,874 & 1,940 & 1,929 & 1,684 \\
\hline $\begin{array}{l}\text { Non-metallic building materials - } \\
\text { total of which: }\end{array}$ & thous. $\mathrm{m}^{3}$ & 23154 & 27029 & 29819 & 34315 & 36567 & 41621 & 43785 \\
\hline rubble stone & -“- & 36,1 & 130,1 & 66,9 & 49,3 & 69,3 & 107,9 & 104,1 \\
\hline crushed stone & -“- & 8553 & 9493 & 10100 & 10753 & 11338 & 12089 & 13152 \\
\hline mortar sand & -“- & 8934 & 10343 & 11137 & 11256 & 12720 & 15835 & 16677 \\
\hline gravel & -“- & 649 & 781 & 1069 & 1448 & 1410 & 1369 & 1673 \\
\hline $\begin{array}{l}\text { Glass - (all totally for SUP. } \\
\text { Elektroarmaturnogo glass), including } \\
\text { by type: }\end{array}$ & thous. $\mathrm{m}^{2}$ & 23746 & 23249 & 21268 & 21357 & 20880 & 21364 & 25354 \\
\hline building glass & -“- & 1461 & 1322 & 1370 & 1130 & 1419 & 1711 & 1948 \\
\hline polished glass & -“- & 20349 & 20151 & 18022 & 18428 & 17551 & 17275 & 20606 \\
\hline glass (stalinite) & -“- & 93 & 130 & 153 & 138 & 101 & 121 & 160 \\
\hline patterned glass & -“- & 475 & 397 & 420 & 558 & 380 & 546 & 692 \\
\hline glass reinforced & -“- & 966 & 833 & 951 & 791 & 1138 & 1384 & 1720 \\
\hline Glass elektroarmaturnoe & thous.unit & 402 & 416 & 352 & 312 & 291 & 327 & 228 \\
\hline \multicolumn{9}{|l|}{ Ferrous metallurgy } \\
\hline Cast iron & thous. tonnes & 270 & 301 & 346 & 366 & 276 & 303 & 359 \\
\hline
\end{tabular}


Sproge I., Curkina I., Jekabsone S., Tsilibina V., Rumyantseva J., Piletsky K. PRODUCTION AND FOREIGN TRADE OF MINERAL PRODUCTS IN LATVIA AND BELARUS

\begin{tabular}{|l|l|l|l|l|l|l|l|l|}
\hline Steel & -“- & 2076 & 2297 & 2387 & 2660 & 2449 & 2672 & 2779 \\
\hline Finished rolled products & $-“-$ & 1839 & 2047 & 2192 & 2470 & 2298 & 2458 & 2454 \\
\hline Steel pipes & $-“-$ & 108 & 134 & 148 & 146 & 107,4 & 183,7 & 218 \\
\hline Metal cord & $-“-$ & 78,5 & 86,4 & 87,2 & 96,5 & 68,5 & 92,9 & 94,1 \\
\hline
\end{tabular}

In the depths of Belarus found over 10 thousand deposits of various mineral resources, the most important of which are fields of energy resources (oil, associated gas, peat, lignite and oil shale), potash and rock salt, variety of minerals used in the production of building materials (building and facing stone, raw materials for the production of cement, lime, sand and glass construction, sand and gravel material, clay ceramic, refractory and lightweight aggregates, and other), fresh and mineral underground waters. In addition, deposits of iron ore, gypsum, rare metals, phosphorus, alumina-soda raw materials and industrial brines were identified. While Belarus buys oil, gas, raw materials for steel production, facing stone, glass sand, bentonite and kaolin clay, plaster and building materials based on gypsum, apatite, phosphorus.

The Republic of Belarus is now being developed oil fields, peat, potash and rock salt, dolomite, fresh and mineral underground waters on the basis of which work successfully industry.
At the present stage of development and the future site of the mineral resources base of Belarus is sufficient to provide of mineral commodities only industry of building materials (except for the production of glass), chemical and petrochemical industries in the production of potash and nitrogen fertilizers and fuel industries of the country.

Almost all industries have a high degree of dependence on imported mineral commodities and mineral resource production, which adversely affects the competitiveness of commercial products, the formation of the balance of foreign trade of the Republic of Belarus and the state of the economy as a whole.

Mineral resources play a dominant role in the commodity structure of foreign trade of the Republic of Belarus: in 2010 year, their share of total exports amounted to $28.2 \%$ and $35.4 \%$ of total imports. In 2011 year $-36.0 \%$ of total exports and $41.7 \%$ of total imports (Fig. 1, 2).

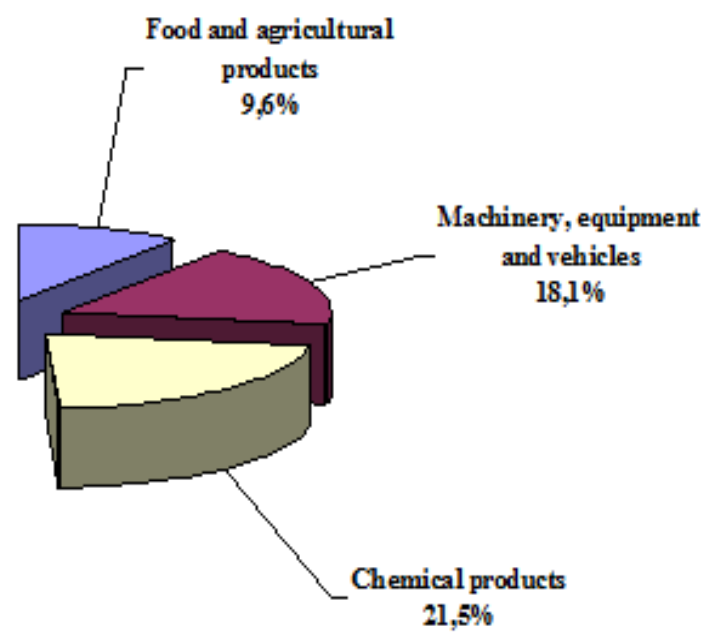

Fig. 1. - Commodity structure of exports in Belarus, 2011

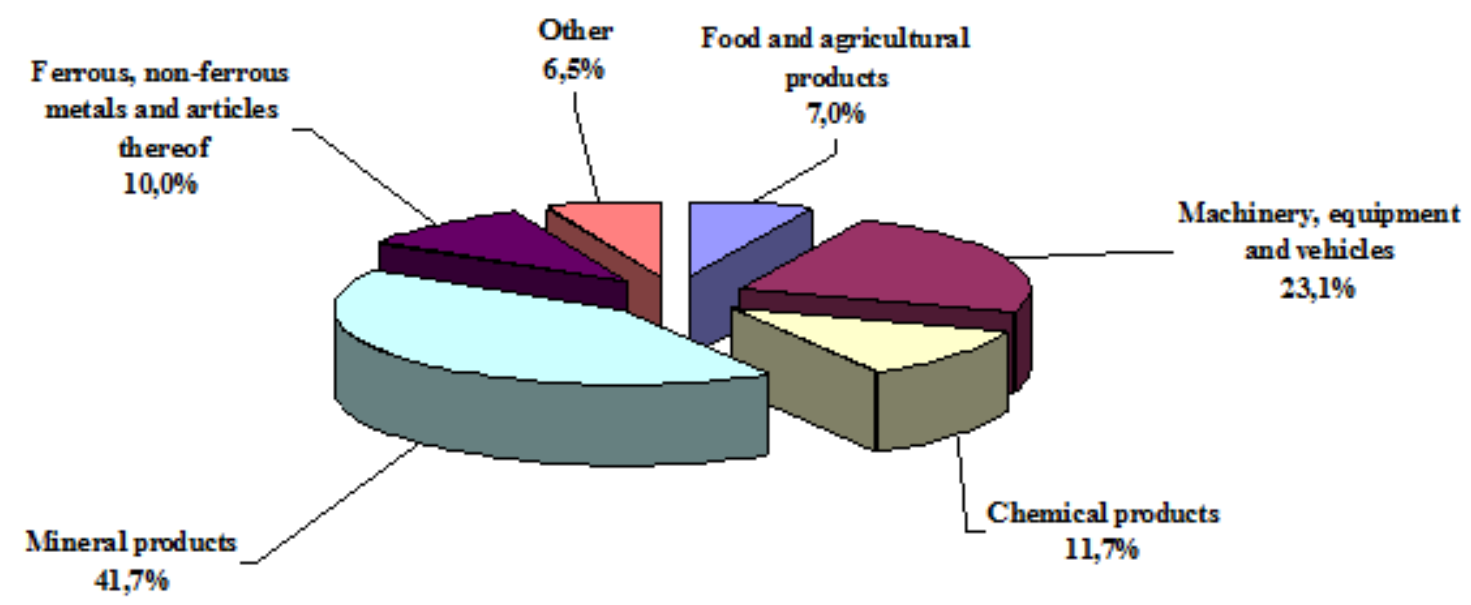

Fig. 2. - Commodity structure of imports in Belarus, 2011. 
The main consumers of exports from Belarus mineral commodities are Russia, Ukraine, Moldova, Lithuania, Latvia, Poland [4, p. 25].

Given that the mineral resources is the basis of national security and sustainable development, to regulate its formation should be special state programs.

Belarus has adopted and implemented legal normative acts, which are a part of the national legislation, aimed at integrated use of mineral resources, including fuel and energy resources, improving performance for the involvement in the development of mineral deposits:

State exploration program for the development of mineral resources of Belarus for 2006-2010 and for the period up to 2020, approved by Edict of the President of the Republic of Belarus from 28 March 2006 № 184 [5],

Subsoil Code of the Republic of Belarus (14 July 2008),

The development strategy of the energy potential of the Republic of Belarus, approved by the Regulation of the Council of Ministers of the Republic of Belarus from 9 August 2010 № 1180 [6],

The program of development of mineral deposits and the development of mineral resources of the Republic of Belarus for 2011-2015 and for the period up to 2020, approved by the Regulation of the Council of Ministers of the Republic of Belarus from 4 April 2011 № 431 [7],

Water Code of the Republic of Belarus (15 July 1998),

National program of local and renewable energy sources for the period 2011-2015, approved by the Regulation of the Council of Ministers of the Republic of Belarus from 10 May 2011 № 586, etc.

Regulation similar public relations for the use of mineral resources, including fuel and energy resources, is carried out in the Russian Federation and other countries - members of the Commonwealth of Independent States [8, p. 131], and in the Commonwealth of Independent States. In particular, the basis of international legal cooperation among states in the use of mineral resources are:

Mining Charter of countries - members of the Commonwealth of Independent States from 27 March 1997 ,

Pact on cooperation in the field of exploration, development and use of mineral resources from 27 March 1997,

Pact on the basic principles of cooperation in the field of rational use and protection of transboundary waters from 11 September 1998,

Pact on cross-border cooperation in the field of exploration, development and protection of the subsoil from 31 May 2001,

Pact on cooperation of countries - members of the Commonwealth of Independent States in the field of energy efficiency and energy savings from 7 October 2002, and

Memorandum of Cooperation between the Government of the Republic of Belarus and the Government of Latvia in the energy sector from 18 February 2009 [9].

Of particular interest to Belarus is expanding economic ties with the Baltic states - Lithuania, Latvia and Estonia. This is due to many factors, among which is the geographical proximity, and the overall economic past [10, p. 341].

Improving the legal security subsoil and the introduction of economic incentives of geological study of the subsoil and reproduction of mineral resources and the rational use of mineral resources will increase the investment attractiveness of the subsoil, to remove administrative barriers in regulating geological study of the subsoil and reproduction of mineral raw materials.

\section{CONCLUSIONS}

The share of value added, created in mining and quarrying industry in Latvia in 2011 was $0.5 \%$ of GDP.

Belarus is an important petroleum, petroleum product and related material import market for Latvia. $69 \%$ of the petroleum import value is attributable to the EU-27, 24\% to Belarus and $7 \%$ to other countries outside the European Union.

In 2010 and 2011 trade in construction materials (lime, cement, and fabricated construction materials) turned to a positive balance of Latvian foreign trade with Belarus.

Mineral resources play a dominant role in the commodity structure of foreign trade of the Republic of Belarus: in 2011 year, their share of total exports amounted to $36 \%$ and $41.7 \%$ of total imports.

The strategic goal for Belarus is to increase the security of the country's own organic and mineral resources, a rational use and minimizing the negative impact of extraction on the environment, reducing the dependence on imports, as well as improving the quality of use of surface and ground water.

To achieve this goal in Belarus it is necessary:

-to improve the economic mechanism of production and use of mineral resources for complex processing environment;

-develop a comprehensive state program for the development of mineral resources of the country in which the strategy of exploration industry should be closely linked with the economical use of natural resources and increasing need in their separate ways;

-oriented economy to rational use of mineral resources;

-ensure the expansion of exploration on promising areas, the search for new deposits, as well as the use of related types of minerals, certain types of waste and recycled materials; 


\section{Sproge I., Curkina I., Jekabsone S., Tsilibina V., Rumyantseva J., Piletsky K. PRODUCTION AND FOREIGN TRADE OF MINERAL PRODUCTS IN LATVIA AND BELARUS}

-support material and technical base of exploration industry at an optimal level;

-improve the regulatory framework in the sphere of subsoil use in order to ensure the best possible country own minerals.

\section{ACKNOWLEDGMENTS}

This study was supported by the Belarusian Republican Foundation for Fundamental Research (BRFFR). Project № Г12ЛАТ-018 of June 1, 2012.

\section{REFERENCES}

[1] LR CSB data base. [Online]. Available: http:data.csb.gov.lv Accessed: Mar.12,2013

[2] Annual detailed enterprise statistics for industry (NACE Rev.2

E)[sbs_na_ind_r2]. Eurostat. [Online]. Available: http://epp.eu rostat.ec.europa.eu. [Accessed: Feb.15,2013]

[3] Eurostat. [Online].

Available: http://epp.eurostat.ec.europa.eu. [Accessed: Feb.15,2013]

[4] Унукович, А. В. Геолого-экономическая оценка месторождений полезных ископаемых Беларуси / А. В. Унукович, Я. И. Аношко ; науч. ред. А. К. Карабанов. Минск : Беларус. навука, 2012. - 455 с.
[5] Государственная программа геологоразведочных работ по развитию минерально-сырьевой базы Беларуси на 20062010 годы и на период до 2020 года, утв. Указом Президента Респ. Беларусь, 28 марта 2006 г., № 184 // Нац. реестр правовых актов Респ. Беларусь. - 2006. - № 53. 1/7390; 2009. - № 292. - 1/11132.

[6] Стратегия развития энергетического потенциала Республики Беларусь, утв. постановлением Совета Министров Респ. Беларусь, 9 авг. 2010 г., № 1180 // Нац. реестр правовых актов Респ. Беларусь. - 2010. - № 198. $5 / 32338$.

[7] Программа освоения месторождений полезных ископаемых и развития минерально-сырьевой базы Республики Беларусь на 2011-2015 годы и на период до 2020 года, утв. постановлением Совета Министров Респ. Беларусь, 4 апр. 2011 г., № 431 // Нац. реестр правовых актов Респ. Беларусь. - 2011. - № 43. - 5/33617.

[8] Минерально-сырьевое обеспечение Республики Беларусь: состояние, проблемы, пути решения / П.Г. Никитенко [и др.]; под науч. ред. П.Г. Никитенко. - Минск: Беларус. навука, 2012. - 211 с.

[9] Меморандум о сотрудничестве между Правительством Республики Беларусь и Правительством Латвийской Республики в энергетической сфере, 18 февр. 2009 г. // Нац. реестр правовых актов Респ. Беларусь. - 2009. - № 71. $3 / 2226$.

[10]Ноосферное развитие Беларуси: теория, методология и практика / П.Г. Никитенко [и др.]; Ин-т экономики НАН Беларуси. - Минск: Белорус. наука, 2009. - 352 с.

[11]Национальный статистический комитет Республики Беларусь. 